\title{
Manipulation of Poetic Language: Fragmentation of the Visible in Du Bellay's Les Antiquitez de Rome
}

\author{
Vivian A. Brown \\ Morehouse College (Atlanta)
}

Much has been said about the ruins motif as an artistic device in Les Antiquitez de Rome. Ingrid Daemmrich in her article "The Function of the Ruins Motif in Du Bellay's Les Antiquitez de Rome," echoes the opinion of many literary critics when she explains how the decay and destruction ever present in Les Antiquitez de Rome symbolize the futile efforts of man to produce a lasting monument to his glory and the victory of time, chance and fate over his majestic achievements. ${ }^{1}$ Dorothy Coleman in like manner states that the sonnet sequence is a detached contemplation of the inconstancy of things, woven around the "sic transit gloria mundi" topos, and suggests a "désenchantement" with the world. ${ }^{2}$ Alfred Satterthwaith agrees, demonstrating that it is possible to view Du Bellay's poem as united by a single theme: the inconstancy of all sublunary things. ${ }^{3}$ Other critics for example, Thomas Green, emphasize the imagery of exhumation, bringing to light, the theme of archaeological probing and physical restoration which can be found in the sonnet sequences. ${ }^{4}$

Certainly these are all valid interpretations of Du Bellay's famous sonnet. However, few authors have attempted to fully explore in Les Antiquitez Du Bellay's use of the poetic imagery of the ruins to shape, manipulate and transform the image of the king.

This image, the representation of the king that is presented to the world, is fully under the control of the writer through his literary creations. The usefulness of literature in the propagation of the royal image is an important element of Du Bellay's 
poetic theory as presented in La Deffence et illustration de la langue francoyse. The task of the poet is to inscribe perpetuity into the image of the king so that whether "presens, absens, vyfz et mors," 5 the public is presented with a glorious representation of the king's character. Du Bellay presents the poet as the manipulator and purveyor of the goods which can be obtained from literary creativity. His power is shown through the control that he exercises over the poetic image and Du Bellay demonstrates through Les Antiquitez, as we are about to see, his ability to modify, consume, destroy or appropriate certain images.

Louis Mantras explains that by representing the monarch in a text, the poet ineluctably reconstructs the monarch as a textual product. ${ }^{6}$ This upsets the traditional relationship between the poet and the king and in Du Bellay's redefinition of the role of the poet, the latter is seen as exercising power over the king. The political impact of such a role reversal is made explicit in Les Antiquitez as we discover how the poet uses violence to obliterate, to transform or to modify the poetic image of Rome's glory. Violence in his imagery is shown to be an instrument of reordering and reconstruction.

In sonnet 4 we see the evidence of this reordering or restructuring of Rome's glory:

Celle qui de son chef les estoilles passoit

Et d'un pied sur Thetis, l'autre dessous l'Aurore,

D'une main sur le Scythe, et l'autre sur le More,

De la terre, et du ciel, la rondeur compassoit:

Juppiter ayant peur, se plus elle croissoit,

Que 1'orgueil des Geans se relevast encore,

L'accabla sous ces monts, ces sept monts qui sont ore

Tumbeaux de la grandeur qui le ciel menassoit.

Il luy mist sur le chef la croppe Saturnale,

Puis dessus l'estomac assist la Quirinale,

Sur le ventre il planta l'antique Palatin:

Mist sur la dextre main la hauteur Celienne,

Sur la senestre assist l'eschine Exquilienne,

Viminal sur un pied, sur l'autre l'Aventin.? 
In the first stanza, Du Bellay constructs the image of a proud and glorious Roman Empire, her head lifted high above all other empires, past and present : “... Celle qui de son chef les estoilles passoit." The second and third verses of this stanza are used by Du Bellay to evoke feelings of admiration for the vast expanse of the empire's borders. "Et d'un pied sur Thetis, l'autre dessous l'Aurore." The mention of Thetis, the mythological sea goddess, combined with the image of Rome ruling the morning skies, sends a message that Rome's power extends well beyond the seas and around the world. Joukovsky indicates that the geographical periphrasis in verse 3 is often used by writers of this period "pour évoquer le rêve de la puissance de la Rome antique."8

"Comme les néolatins italiens, (Du Balley) admire l'étendue de l'empire. Ce pouvoir s'égale au monde, au grand tout, à la rondeur du globe, à la terre et à la mer, et touche aux contrées les plus lointaines. ${ }^{9}$

Rome is presented at its pinnacle of greatness. Then Du Bellay reverses the image, and the reader is a startled witness to its utter destruction and entombment as described in the latter stanzas of this sonnet.

In sonnet 2, the seven hills of Rome were praised as seven monuments of greatness. Now in sonnet $4, \mathrm{Du}$ Bellay deconstructs, not a colossus of greatness, but "... Tumbeaux de la grandeur."

L'accabla sous ces monts, ces septs monts qui sont ore

Tumbeaux de la grandeur qua le ciel menassoit. (vv. 7-8)

Let us examine now more closely this new construction which Du Bellay fashions out of his vast poetic resources. The seven hills which were used in the first part of the sonnet to exalt Rome are now arranged in such a way in the latter part of the sonnet to entomb Rome.

Il luy mist sur le chef la croppe Saturnale, Puis dessus l'estomac assist la Quirinale, Sur le ventre il planta l'antique Palatin

Mist sur la dextre main la hauteur Celienne,

Sur la senestre assist l'eschine Exquilienne, Viminal sur un pied, sur l'autre l'Aventin. 
Rome which was at first pictured as standing upright, supported by the hills, her head reaching ot the sky, is now sprawled on the ground, the hills no longer a support, but a crushing instrument of annihilation. Each of the seven hills, the Saturnale, the Quirinale, the Palatin, the Celienne, the Exquilienne, the Viminal, and the Aventin, has been "textually reconstructed" 10 to fit the purposes of the author. The Rome that was alive and governing the world in the first stanza is now dead. The seven hills, the pedestal, upon which she once stood has now been reconstructed and become her tomb.

The overwhelming power of the poet is demonstrated by this sudden reversal of Rome's fortune. Michel Foucault explains that power manifests itself through the force which is exerted over things and through the ability to modify, use, consume or destroy. ${ }^{11}$ In sonnet 4, Du Bellay has indeed, as we have shown, modified at will the vision of Rome which is presented to the reader. The power of the poet somehow is inscribed in the body of Rome using the seven hills. This inscription is emphasized by the language Du Bellay uses to describe the burial of Rome. Let us consider for instance the verb "accabla" in verse 7. In modern French, it can be interpreted as meaning to crush, to weigh down or to overburden, but in the sixteenth century this verb enjoyed another semantic interpretation, "attaquer par la parole."12 It is through the manipulation of the language that $\mathrm{Du}$ Bellay attacks Rome and asserts his power. In verse 9 the reader witnesses the inscription of the poet's power on the literal head of Rome: "Il luy mist sur le chef la croppe Saturnale." The head, which once dwelt among the stars is now not only abased and buried beneath the earth, but the poet further humiliates the city by insulting it and placing it beneath "la croppe Saturnale." Du Bellay has demonstrated his power to control the image of Rome by transforming the image of glory in the first verse into an image of shame (verse 9).

In verses 10 and 11 the author continues to inscribe his power in the body of Rome: "Puis dessus l'estomac assist la Quirinale / Sur le ventre in planta l'antique Palatin."

From the head Du Bellay moves directly to the disembowelment and entombment of the torso represented here by the words "estomac" and "ventre." The torso contains the vital organs which perform the various life sustaining and reproductive functions of the body. The violence of this radical destruction of the old authority, represented by the body of Rome is necessary in order for the poet to assert his new authority. 
This violence is also manifested in La Deffence, as Du Bellay calls for the pitiless desecration of Rome:

La donq', Francoys, marchez couraigeusement vers cete superbe cité romaine et des serves depouilles d'elle .... (DI 338)

The same phrase in this passage which flatters Rome "cete superbe cité romaine," also calls for her destruction, "des serves depouilles d'elle." Further on in La Deffence, Du Bellay repeats this same pattern of flattering and insulting Rome, which we found in the fourth sonnet:

Pillez moy sans conscience les sacrez thesors de ce temple delphique, ainsi que vous avez fait autrefoys: et ne craignez plus ce muet Apollon, ses faulx oracles, ny ses fleches rebouchées. (DI 340)

Maragaret Ferguson describes this attitude as a "vacillation between sacramental réverence and violence." 13 Rome is lauded by Du Bellay for being the source of truth and enlightenment for the civilized world. These are the "sacrez thesors" which he so often glorifies. Rome is continually praised for being the source of "rare et antique erudition" (DI 209) from which the philosopher, concerned with the essential problems of man in his world and with the definition of man's relation to nature and to God, is able to form a valid interpretation of life.

Ferguson makes these remarks in her article, "The Exile's Defense: Du Bellay's 'La Deffence et illustration de la langue francoyse," concerning the reverent and critical attitudes that Du Bellay displays toward Rome in Les Antiquitez:

The sequences offer ... another instance of an oscillation between a defensive (reverent) and offensive (critical) rhetoric ... the poet demystifies and mystifies Rome, criticizes and admires it. In Les Antiquitez Du Bellay combines his attitude of reverent humility toward the "Divins Esprits" with a critical examination of Roman history. He frequently blames Roman hubris for causing the city's downfall and often alludes to the myth of genealogical warfare between the giants and the Olympian gods to portray Roman history as a series of violent struggles for supremacy...14 
Du Bellay uses these images of legendary or historical violence as a metaphorical instrument to manifest his purposes of reordering the reconstruction. It is by means of the poet's transforming power that the ancient authorized sources of literary power are, like Apollo, rendered mute and their oracles, though not declared false, are clearly now the possession of the modern poet.

$\mathrm{Du}$ Bellay is showing through his dismemberment of the glorious city and his restructuring of its parts that this authority now resides with the sixteenth century poet. Literary creativity, which the poet needs to "textually reconstruct"15 the image of the King, necessarily begins with a transgression. ${ }^{16}$ In Du Bellay's case, his transgression is the barbaric attack upon the person of Rome:

... his desire to write challenges the ideal, presupposes the necessity of its replacement; his materials will be fragments of its dismembered corpse. ${ }^{17}$

The emphasis on the dismembered corpse of Rome establishes itself as a leitmotif throughout the sonnet sequences. The rubble, the ashes are all fragmented body parts which the poet consumes in order to transform Rome's reality into a manipulative commodity. In sonnet 5, we find: "Le corps de Rome en cendre est devallé." In sonnet 7, Du Bellay characterizes Rome as "L'honneur poudreux" and he continues with:

Las peu à peu cendre vous devenez,

Fable du peuple, et publiques rapines!

Oeuvres et noms finablement atterre.

(vv. 7-8, 11)

In sonnets 14 and 15 we find these references to the famous city: "ces poudreux tumbeaux, umbres poudreuses, reliques cendreuses." By representing the world in discourse, writers are engaged in constructing the world and accommodating persons, places and things to positions within it. ${ }^{18}$ Du Bellay's portrait of Rome becomes a work of deconstruction and fragmentation as the poet repeats the same descriptive terms: "poudreuse cendre, poudreuses reliques, pouldreuse plaine, poudreuses ruines." He asserts his authority in this discourse of Rome by taking the ruined elements and relegating them to positions of dishonor. By rearranging the elements and 
constructing a world where the king's monuments are abased, Du Bellay is undermining the king's authority while at the same time elevating the poet's authority. The poet becomes the one who determines the fate of the kings' monuments and in this capacity he positions himself to transform the king's image. In sonnet 18, for example, what was earlier referred to as "sacrez costaux" and "ces braves monts" are now called "ces grands monceaux pierreux." Accordingly, we can now see in Du Bellay's discourse of the ancient capital that he interjects the constant theme of solidity versus fragmentation, wholeness versus incompleteness.

Ces grands monceaux pierreux, ces vieux murs que tu vois, Furent premierement le cloz d'un lieu champestre:

Et ces braves palais, dont le temps s'est fait maistre,

Cassines de pasteurs on esté quelquefois. (vv. 1-4)

The once magnificent walls of Rome are first pictured as an intact structure, "murs," secondly, they are pictured in pieces, "monceaux pierreux," and finally we see them in a humble surrounding: "le cloz d'un lieu champestre." In order to construct a new vision of Rome while at the same time asserting his authority the poet has to de-solidify the hard substances, (in this case the process used is pulverization) and rearrange the elements. In appropriating the kings' monuments and placing them in a different, more humble position, the poet proves his superiority.

The poet also shows his ability to master time with his poetic images. In verse 3 of this sonnet, he evokes the past glory of Rome, "ces braves palais...," while at the same time reminding the reader of their present state of decay, "... dont le temps s'est fait maistre." He then immediately returns to the far distant past, to the humble beginnings of Rome before these stones were used to construct Roman palaces. In this distant time they were part of the "cassines de pasteurs." Next the author begins once more a forward progression in chronological time:

Lors prindrent les bergers les ornemens des Roys,

Et le dur laboureur de fer aima sa dextre: (vv. 5-6)

In Les Antiquitez the reader is presented with images that are not situated and delimited in chronological time. We have just seen how the author uses his authority to move at will from the past to the present to an even further distant past. Reversing the direction, the author, as we have seen, then moves progressively forward. Daniel Russel, in his article "Du Bellay's Emblematic Vision of Rome," feels 
that Du Bellay is in the process of reconstructing the cultural and historical continuity of Rome which he had not found as a humanist tourist. ${ }^{19}$ I would say, however, that Du Bellay's reconstructive undertakings are not primarily efforts to maintain an historical continuity, but efforts to show his ability to manipulate and transform the image of Rome's glory. He has taken the architecture of the king and shown how its solidness and its rigidness eventually works against it with the passage of time. The stone edifices of the king are locked into the past, in a fixed moment in time. These fixed edifices, once erected, cannot move from the past to the present. The process of the erosion by time then begins. When Du Bellay returned to the actual sight of Rome, the glory of these monuments had been erased.

Du Bellay has taken his architecture, the architecture of poetry and shown how, using it, he can move at will through time. He returns to the literary past and, using his poetic language, reconstructs "ces braves palais." As we have seen, his journey takes him even further back to when these stones were first used to construct humble abodes. Du Bellay is showing that his architecture is not locked into a fixed time and place in the historical past. The poet uses the Roman monument to serve as an intermediary point os reference as the reader, by means of poetic imagery, contemplates what was before and what was after this period of greatness. The focus then should be on the value of the monuments constructed with and "enrichy et illustre de motz" (DI 211) which the poet uses to give immortality. The free movement of the poetic image back and forth through time exemplifies its unending existence and Du Bellay adeptly demonstrates the presence and control of the authoritative voice of the poet.

By creating through poetic language a world where the poet is his own authority, Du Bellay is making an allusion to poetic subjectivity. These are the poet's images. It is within his power to uplift, to abase, to embellish, or to vilify these images. Answerable to no higher authority, the poet uses the language to produce an architectural structure which can be continually visualized, refreshed and renewed. In this way he uses the language as a means of creating a type of perpetuity which is implanted with his ideas and totally governed by him.

In addition to his images not being situated and delimited in chronological time, Du Bellay's images are also not limited ot one specific shape or form. The poet, in keeping with the theme of solidity or wholeness versus fragmentation, reserves the right to separate, to co-mingle, to shut-up and to release these images in any manner whatsoever, no matter how unwonted. Consider for example sonnet 19: 
Tout le parfait dont le ciel nous honnore,

Tout l'imparfait qui naist dessous les cieux,

Tout ce qui paist noz esprits et noz yeux

Et tout cela qui noz plaisirs devore:

Tout le malheur qui nostre aage dedore,

Tout le bon heur der siecles les plus vieux,

Rome du temps de ses premiers ayeux

Le tenoit clos, ainsi qu'une Pandore.

Mais le Destin, débrouillant ce Chaos,

Où tout le bien et le mal fut enclos,

A fait depuis que les vertus divines

Volant au ciel on laissé les pechez,

Qui jusqu'icy se sont tenus cachez

Sous les monceaux de ces vieilles ruines.

The image of all inclusiveness and completeness is emphasized and reinforced by the repetition of the word "Tout" in verses 1 through 6 . The entire sonnet is composed of two sentences and upon the completion of the first sentence, we discover the termination of the image of wholeness and the reintroduction in the sonnet sequences of the image of fragmentation and disruption.

Before considering the controlled disorder that the poet unleashes in the second half of sonnet 19, let us examine the abstract nouns enumerated in the first part of this sonnet. The poet talks in specific terms of : "le parfait, l'imparfait, le malheur" and "le bon heur." He also uses the unspecific expressions : "Tout ce qui paist noz esprits et noz yeux, / Et tout cela qui noz plaisirs devore," as if to include all the grey areas of perfection/imperfection and good/evil. It is worth noting that the grey areas between the abstract oppositions include the human, fleshy, earthbound elements of eating and devouring: "Tout ce qui paist ... / ... tout cela qui noz plaisir devore."

Turning our attention to the abstract expressions, we see in line one that all perfection (verse one) without exception comes from heaven and all imperfections have their origin it the earth (verse 2). The present age, "nostre aage," is presented by the poet as incorporating all that is evil. This is no doubt a subtle reference to the present state of decay of the "eternal " city. Notice in this verse that the poet speaks in terms 
of the evil that permeates this age, "dedore." If we examine all the sonnets to see what Du Bellay mentions specifically as adorning the city when viewed through the eyes of a sixteenth century visitor, we return one again to the oft repeated "poudreuse cendre" which blankets the "murs, reliques," and "plaines" of Rome. The expression "Tout le malheur" affirms the author's sentiments that visible Rome in its entirety is in a state of disintegration.

At the same time that the whole of Rome is pictured as crumbling under a blanket of decay, Du Bellay presents in the next line a Rome which incorporates within its borders "Tout le bonheur des siecles ..." The contradiction and impossibility of an object incorporating two wholes becomes possible only through poetic imagery and limitless poetic authority. The six expressions of wholeness in verses 1 through 6 are all fused into one whole and become a complete expression of the poet's vision of Rome:

Rome du temps de ses premiers ayeux

Le tenoit clos ... (vv. 7-8)

This vision is continued in the latter half of the sonnet where there is a supernatural separation of the entities of good and evil when "...les vertus devines / volant au ciel ont laissé les pechez, / Qui jusqu'icy se sont ténus cachez / Sous les monceaux de ces vieilles ruines." This image allows one to imagine time's consuming power at work. It is because the destructive forces of time have left the city in such a ruined state that no truth or beauty remains enclosed in its walls. The deteriorating corps is no longer a suitable dwelling place for the works of immortality. Stone edifices therefore, as Du Bellay wishes the reader to conclude, are not suitable guardians for the king's glory. There can be no hope of glory "Sous les monceaux de ces vieilles ruines" without the reconstructive efforts of the poet.

A further significant feature of this sonnet is that Du Bellay uses several expressions to reintroduce his ideas concerning the importance of the temporality that the poet inscribes in his images. References to the beginning of man's time and to the beginning of sorrows can be found in this sonnet. "Tout l'imparfait qui naist" and "... ainsi qu'une Pandore" is a mythological reference which also marks this beginning. An allusion to eternal time and perfection can be found in the reference to "Tout le parfait dont le ciel nous honnore." It is worth noting that perfection is linked to eternal time (v.1) and imperfection is linked to mortality. (v.2) This same idea is expressed in the concluding tercets where we find "... les vertus divines / Volant au 
ciel ..." (vv. 11-12) and "... les pechez, / ... se sont tenus cachez / Sous les monceaux de ces vieilles ruines." Hence, Du Bellay's poetic language links the objects which are inscribed with perfection to "le ciel" and the objects which are perishing to "dessous le ciel or "sous ... ces vieilles ruines. Notice that "les vertus divines" defy time by escaping, "volant au ciel," whereas "les pechez" become the victim or captive of time: "ce sont tenus cachez / sous les monceaux de ces vieilles ruines."

Turning to the other references to time in sonnet 19, we find "le malheur (v. 5), the bad time and "le bon heur," (v. 6) the good time. Both these "times" which Rome endures have fixed limits : "nostre aage," "des siècles." The "Rome du temps..." described in the second quatrain by these expressions is situated and delimited in chronological time and therefore, the king's monument to his glory, Rome, fails in relation to time. "Ces vieilles ruines" represent all that remains of the "Rome du temps." We see that in the next to the last tercet "le bien" and "le mal" are both intermingled: "...ce Chaos, / où tout le bien et le mal fut enclos." The poet's efforts consequently are efforts to inscribe in the image of Rome a temporal dimension, removing "le mal" which is linked to mortality and enhancing "le bien" which is linked to the eternal; thereby transforming "le mal heur" (malheur) into "bon heur" (bonheur).

The opposing poles of "le bien" et "le mal," "good" architecture and "bad" architecture, as we have seen evidenced throughout Les Antiquitez, serves several purposes. First of all, this dialectic serves as a method by which Du Bellay can highlight and contrast the differences between monuments of stone and the poetical monuments of the writer. Du Bellay uses it to show the disadvantages of solid objects made of rigid, inflexible substances and the advantages of poetic language which is flexible and fluid and the appropriateness or inappropriateness of one or the other when used to glorify the king. Secondly, this dialectic serves as a convenient vehicle for continual praise of the poet throughout the poem as his poetic constructions are repeatedly shown in sonnet after sonnet to be superior to the kings' undertakings. In addition this dialectic puts on display the ability of the poet to use his poetic imagery to convert into his own substance the solid, rigid, ruined edifices of failed attempts by others to obtain immortality. Specifically, the dialectic of Les Antiquitez highlights the poet's conversion of the solid into the fluid and flexible as he uses the fragments of the city to make a literary construction which can at the poet's whim bring honor or dishonor.

In the sonnet sequences, Du Bellay has shown how he can take the fragments of ruined edifices, transform them into manipulative literary building blocks and rebuild 
Rome. Implicit in this demonstration is that writing can be used to fashion the king's immortality through the constant reordering and restructuring of language fragments. The poet's ability to inscribe temporality into the image of the king, thus building a monument which will constantly be reformed and reinscribed in time and which will last throughout history, affirms the poet's superiority. Consequently, the poet's superior position as redefined by Du Bellay in Les Antiquitez becomes unassailable.

\section{Notes}

${ }^{1}$ Ingrid Daemmrich, "The Function of the Ruins Motif in Du Bellay's Les Antiquitez de Rome," Neophilogus 59 (1975): 16.

2 Dorothy Coleman, The Chast Muse (Leiden: E.J. Brill, 1980) 91.

${ }^{3}$ Alfred Satterthwaith, Spenser, Ronsard and Du Bellay, A Renaissance Comparison (Princeton: Princeton University Press, 1960) 93.

4 Thomas M. Green, "Resurrecting Rome: The Double Task of the Humanist Imagination:" Papers of the 14th Annual Conference of the Center for Medieval and Early Renaissance Studies, Paul A. Ramsey, ed., Rome in the Renaissance, the City and the Myth Binghamton XVIII (1982), 41, 44.

5 Joachim Du Bellay, La Deffence et illustration de la langue francoyse, (Genève: Slatkine Reprints, 1969) 132. All subsequent references to La Deffence will be taken from this edition and will be noted in the text by the abbreviation DI and the number(s) of the corresponding pages (s).

6 Louis Mantras, "The Elizabethan Subject and the Spenserian Text," Literary Theory/Renaissance Texts Patricia Parker and David Quint, ed., (Baltimore: Johns Hopkins University Press, 1986) 322.

7 All quotations from the Antiquitez are drawn from Albert-Marie Schmidt, ed., Poètes du seizième siècle (Paris: Librairie Gallimard, 1953) 418-437. 
${ }^{8}$ Francoise Joukovsky, La Gloire dans la poésie française et néolatine du XVIe siècle (Genève Librairie Droz, 1969) 233.

9 Joukovsky 233.

10 This term is based on Mantras remarks that the poet "reconstructs the monarch as a textual product. Mantras 322 . Not only can persons be "textually reconstructed," but places and ideas also.

11 Michel Foucault, "The Subject and Power," Critical Inquiry 8 (1982) : 786.

12 "Accabler," Petit Robert, 1985.

13 Margaret Ferguson, "The Exile's Defense: Du Bellay's 'La Deffence et illustration de la langue francoyse,' PMLA 93 (1978): 277.

14 Ferguson 277, 278 note 10.

15 See note 10.

16 Terence Cave, The Cornucopian Text (Oxford: Claredon Press, 1979) 179.

17 Cave 179.

18 Mantras 306.

19 Daniel Russell, "Du Bellay's Emblematic Vision of Rome," Yale French Studies XLVII (1972), 109. 